\title{
ASPEK MORAL DAN ETIKA \\ DALAM BERKOMUNIKASI ANTAR MANUSIA
}

\author{
Baharuddin
}

\begin{abstract}
Abstrak
Secara global aspek moral dan etika dalam kehidupan manusia merupakan hal yang sangat penting diperhatikan dengan baik.Aspek moral dan etika dalam melakukan komunikasi antar manusia harus benar-benar dijalani dengan baik secara menyeluruh. Demensi awal manusia itu dibentuk dari proses rumah tangga dalam hal ini orang tua yang berperan penting dalm penciptaan dan pembentukan etika dan moral seorang manusia. Guru yang pertama ada bagi anak adalah orang tua, berangkat dari hal tersebut orang tua haris memiliki kemampuan yang tinggi dalam keilmuan baik itu ilmu agama maupun ilmu umum. Hal dilakukan dalam pembentukan moral serta etika yang berkaitan dengan tanggung jawab ilmuan sosiologi terhadap moral manusia memang sangat berat.Berangkat dari hal tersebut seorang sosiolog harus mampu memberikan solusi serta arahan bagi masyarakat dalam berinterkasi serta berkomunikasi.Kerukunan, kedamaian serta ketentraman dalam hidup yang didalamnya masyarakat multikultural harus terciptakan dengan baik.Sehingga keberadaan seorang sosiolog benar-benar diharapan serta menjadikan masyarakat memandang sangat diperlukan.Manusia dalam hidup harus memiliki etika dan moral dalam menjalankan kehidupannya supaya masyarakat hidup dalam kedamaian sejati baik jasmani maupun rohani.
\end{abstract}

Kata Kunci: moral, etika, komunikasi, Manusia

\section{A. Pendahuluan}

Sebelum masuk pada materi tanggung jawab ilmuan sosiologi sebaiknya saya utara kan terlebih dahulu akan makna dari makna aksiologi itu adalah pembahasan mengenai nilai dan moral pengetahuan. Aksiologi juga akan menjawab pertanyaan-pertanyaan tentang kegunaan (untuk) apa pengetahuan itu dipakai. Lebih lanjut membahas tentang kaitan cara penggunaan pengetahuan tersebut dengan kaidah-kaidah yang terdapat dalam moral/etika (akhlak), kaitan antara metode pengetahuan dengan moral moral dalam pencitraan keprofesionalan seseorang dalam menggunakan ilmu pengetahuan serta 
sebagai arah penentu objek yang menjadi bahan telaah didasari oleh beberapa pandangan akan moral dan etika para ilmuan dalam mencari suatu kebenaran. Lebih lanjut aksiologi dikatakan bidang kajian filsafat berupa nilai-nilai menentukan apa yang harus dilakukan manusia.

Aksiologi berkaitan erat dengan masalah baik dan buruk hal ini dinyatakan Louis O. Kattsoff alih bahasa Soejono Soemargono (2003:319) menyatakan bahwa aksiologi ilah ilmu pengetahuan yang menyelidiki hakekat nilai, yang umumnya ditinjau dari sudut pandangan kefilsafatan.Di dunia ini terdapat banyak cabang pengetahuan yang bersangkutan dengan masalahmasalah nilai khusus, seperti ekonomi, estetika, etika, filsafat agama dan epistemologi.

Pada demensi awal manusia itu dibentuk dari proses rumah tangga dalam hla ini orang tua yang berperan aktif dalam menciptakan moral serta etika awal pada seorang anak karena keluarga adalah lingkungan pertama dikenal oleh seseorang manusia baru lahir. Berangkat dari hal tersebut orang tua merupakan faktor primer (utama) yang menentukan perkembangan dan kematangan daya berpikir seorang anak. Komunikasi orang tua kepada anak antara lain bertujuan untuk mengarahkan dan mendidik akhlak dalam kehidupan sehari-hari. Biasanya komunikasi yang berlangsung antara orang tua dengan anak sesuai dengan tingkatan umur anak. Komunikasi akan efektif jika diberikan dalam bentuk contoh langsung kepada anak, terutama akhlak. Penanaman nilai-nilai ajaran Islam seperti penanaman akhlaqul karimah danbudi pekerti yang mulia sesuai dengan Al-Qur'an dan Hadis pada anak agar dapat menyaring berbagai hal dalam menghadapi tantangan dekadensi moral dewasa ini. Moral dari seseorang manusia dapat dinyatakan juga dengan makna akhlak, karena moral dan etika itu melahirkan akhlak mulia.

\section{B. Pembahasan}

Dalam Abdullah Nashih Ulwan (1995 : 437) mengatakan bahwa untuk mempersiapkan anak dalam segi moral, mental, dan spiritualnya, agar ia menjadi manusia saleh untuk agama dan umat, menjadi individu yang bermanfaat dalam keluarga dan masyarakat ada beberapa hal seperti:

1. Membangkitkan minat anak untuk mencari nafkah dengan cara yang paling baik. 
2. Memelihara persiapan naluri anak yang kodrati.

3. Memberi kesempatan kepada anak untuk beriman.

4. Mengadakan kerja sama antar rumah, masjid dan sekolah.

5. Mempererat hubungan antara pendidikan dan anak.

6. Merealisasikan metode pendidikan siang dan malam.

7. Menyediakan prasarana kultural yang bermanfaat bagi anak.

8. Membangkitkan minat anak untuk aktif membaca.

9. Menumbuhkan rasa tanggung jawab anak terhadap Islam

10. Memperdalam jiwa jihad dalam jiwa anak.

Kata akhlak berasal bahasa arab, jamak dari Khuluqun yang menurut bahasa berarti budi pekerti, perangai, tingkah laku atau tabiat. Kata tersebut mengandung segi-segi persesuaian perkataan khalqun berarti kejadian, juga erat hubungan dengan khaliq berarti pencipta; demikian pula dengan makhluqun berarti diciptakan (H.A. Mustofa 1997 : 11).Menurut AlQurthuby dalam Mahyuddin (2001:2) merumuskan defenisi akhlak itu adalah suatu perbuatan manusia yang bersumber dari adab kesopanannya disebut akhlaq, karena perbuatan itu termasuk bagian dari kejadiannya.
Dari uraian tersebut di atas dapat dipahami bahwa komunikasi yang efektif, khususnya pemberian nilai-nilai ajaran Islam pada anak dalam rumah tangga merupakan sesuatu yang sangat penting. Jika hal ini tidak dilakukan, maka akan berdampak pada kemerosotan moral anak remaja. Bahkan orang tua akan meninggalkan keturunan atau anak-anak yang lemah di kemudian hari, baik itu lemah dalam bidang ekonomi, sosial dan khususnya dalam bidang agama. Pentingnya pendidikan akhlak bagi anak dan nilai tauhid serta menjalankan syariah dapat kita lihat misalnya dalam Q.S Luqman ayat 13, 17-19 artinya sebagai berikut:

13. Dan (ingatlah) ketika Luqman berkata kepada anaknya, di waktu ia memberi pelajaran kepadanya: "Hai anakku, janganlah kamu mempersekutukan Allah, sesungguhnya mempersekutukan (Allah) adalah benar-benar kezaliman yang besar.

17. Hai anakku, dirikanlah shalat dan suruhlah (manusia) mengerjakan yang baik dan cegahlah (mereka) dari perbuatan yang mungkar dan bersabarlah terhadap apa yang menimpa kamu. Sesungguhnya yang demikian itu termasuk hal-hal yang diwajibkan (oleh Allah). 
18. Dan janganlah kamu memalingkan mukamu dari manusia (karena sombong) dan janganlah kamu berjalan di muka bumi dengan angkuh. Sesungguhnya Allah tidak menyukai orang-orang yang sombong lagi membanggakan diri

19. Dan sederhanalah kamu dalam berjalan dan lunakkanlah suaramu. Sesungguhnya seburukburuk suara ialah suara keledai. (QS. Luqman : 13, 17-19)

Dari awal perkembangan ilmu selalu dikaitkan dengan masalah moral.Copernicus (1473-1543) yang menyatakan bumi berputar mengelilingi matahari, yang kemudian diperkuat oleh Galileo (1564- 1642) yang menyatakan bumi bukan merupakan pusat tata surya yang akhirnya harus berakhir di pengadilan inkuisisi. Kondisi ini selama 2 abad mempengaruhi proses perkembangan berpikir di Eropa. Moral reasioning adalah proses dengan mana tingkah laku manusia, institusi atau kebijakan dinilai apakah sesuai atau menyalahi standar moral. Kriterianya: Logis, bukti nyata yang digunakan untuk mendukung penilaian haruslah tepat, konsisten dengan lainnya.

Dalam Louis O. Kattsoff alih bahasa Soejono Soemargono (2003:147) menyatakan seseorang penganut skeptisisme mengingkari adanya ada yang dinamakan pengetahuan; atau jika ia kurang ekstrem, ia mungkin mengatakan, sesungguhnya tida ada cara untuk mengetahui pengetahuan. Pendirian ini biasanya didasarkan atas dua unsur: (1) kenisbian penginderaan; dan (2) adanya kesepakatan yang sesungguhnya mengenai apa yang merupakan halnya dan yang bukan merupakan halnya.

Dewasa ini kehidupan masyarakat terasa berat dan konflik kelompok etnik semakin banyak, halhal kecil sering kali menjadi pemicu masalah besar.Berangkat dari berbagai aspek kehidupan masyarakat harus dicermati secara mendalam dan tuntas karena dalam penyelesaian masalah yang ada tidak menemukan kebuntuan.Gesek-gesekan dalam kehidupan itu sebenarnya berangkat dari individu yang menamakan dirinya dari latar belakang kelompok etnik tertentu.Sehingga hal ini memicu hal yang besar kalau tidak cepat diatasi.

Dalam Louis O. Kattsoff alih bahasa Soejono Soemargono (2003:324) menyatakan bahwa sejumlah makna nilai secara singkat dapat dikatakan, perkataan 'nilai' kiranya mempunyai macam makna 
seperti yang tampak dalam contoh berikut:

1. Mengandung nilai (artinya, berguna);

2. Merupakan nilai (artinya, 'baik' atau 'buruk' atau 'indah');

3. Mempunyai nilai (artinya, merupakan objek keinginan, mempunyai kualitas yang dapat menyebabkan orang mengambil sikap 'menyetujui' atau mempunyai sifat nilai tertentu);

4. Memberi nilai (artinya, menanggapi sesuatu sebagai hal yang diinginkan atau sebagai hal yang mengambarkan nilai tertentu).

Ilmuwan sosial harus dapat dengan jeli melihat akar yang memicu sesuatu hal yang dapat menjadi lebih besar. Dalam dunia persaingan global para ilmu dari ilmu sosiologi harus dapat memainkan peran yang dimilikinya dalam menyelesaikan masalah yang sudah, sedang dan yang akan terjadi. Analisa serta evaluasi salah satu jalan terbaik dalam melihat sesuatu hal secara menyeluruh.

Ada 2 cara pokok mendapatkan pengetahuan dengan benar: pertama, mendasarkan diri dengan rasio. Kedua, mendasarkan diri dengan pengalaman.Kaum rasionalis mengembangkan rasionalisme, dan pengalaman

mengembangkan

empirisme.Kaum

rasionalis

mengembangkan metode deduktif dalam menyusun pengetahuannya.Premis yang dipakai dari ide yang diangapnya jelas dan dapat diterima.Ide ini menurut mereka bukan ciptaan pikiran manusia.Prinsip itu sudah ada, jauh sebelum manusiamemikirkannya (idelisme).

Dalam H.A. Mustofa (2009:1819) menyatakan obyek filsafat adalah menelaah hakikat tentang Tuhan, tentang manusia dan tentang segala realitas yang Nampak dihadapan manusia. Ada beberapa persoalan yang biasa dikedepankan dalam mencari obyek filsafat meskipun akhirnya tidak akan lepas dari ketiga hal itu, yaitu:

- Dari apakah benda-benda dapat berubah menjadi lainnya, seperti perubahan oksigen dan hydrogen menjadi air?

- Apakah zaman itu yang menjadi ukuran gerakan dan ukuran wujudsemua perkara?

- Apakah bedanya makhluk hidup dengan makhluk hidup dengan makhluk yang tidak hidup?

- Apakah ciri-ciri khas makhluk hidup itu? 
- Apa jiwa itu? Jika jiwa itu ada, apakah jiwa manusia itu abadi atau musnah?

- Dan manusia ada lagi pertanyaanpertanyaan yang lain.

Dalam H. Sirajuddin Zar (2004:6) menyatakan bahwa objek bahasan filsafat terbagi menjadi tiga bahasan pokok:

1. Al-Wujud atau ontology;

2. Al-Ma'rifat atau epistemology;

3. Al-Qayyim atau aksiologi.

Dalam melihat tugas akan para ilmuan sosiologi sebaiknya terlebih dahulu dipahami sifat hakikat sosiologi itu seperti: Sosiologi adalah ilmu sosial, yang mengkaji hubungan manusia dengan manusia, manusia dengan kelompok dan manusia dengan lingkungannya. Sosiologi bukan disiplin yang normatif, tetapi disiplin yang kategoris, artinya sosiologi membatasi diri pada apa yang terjadi dewasa ini dan bukan apa yang seharusnya terjadi. Sosiologi merupakan ilmu pengetahuan murni dan bukan ilmu pengetahuan terapan.

\begin{tabular}{lr}
\multicolumn{1}{c}{ Tujuan sosiologi r untuk } \\
mendapatkan pengetahuan yang \\
sedalam-dalamnya & tentang \\
masyarakat dan bukan untuk & mengunakan pengetahuan tersebut \\
merhadap masyarakat.Sosiologi \\
merupakan ilmu pengetahuan yang
\end{tabular}

abstrak, artinya yang diperhatikan adalah bentuk dan pola peristiwa dalam masyarakat.Sosiologi bertujuan menghasilkan pengertian-pengertian dan pola umum. Sosiologi meneliti dan mencari apa yang menjadi prinsip, hukum umum interaksi manusia, hakikat, bentuk, isi dan struktur masyarakat. Sosiologi merupakan ilmu pengetahuan yang umum, artinya mempelajari gejala yang umum pada setiap interaksi antar manusia.Jadi sosiologi adalah ilmu sosial yang kategoris, murni, abstrak, berusaha mencari pengertian umum, rasional, empiris dan bersifat umum.

Setelah kita membahas hakikat dari akhlak, moral serta etika selanjutknya akan dibicara tentang tanggung jawab para ilmuan sosiologi terhadap moral dan etika itu memang sudah menjadi hal yang sangat penting karena dengan hal seperti ini memberikan sesuatu amanah dengan sebuah perubahan interaksi sosial kemasyarakatan menjadikan seseorang menjadi berpikir bahwa pengetahuan bukan hanya diciptakan saja tetapi harus ada rasa memiliki serta nilai manfaatnya. Dari hasil kemajuan teknologi yang ada seolaholah membuat dunia ini setara atau masyarakat yang mendiami berbagai 
daerah-daerah seakan-akan memiliki satu prinsip dan satu pandangan. Sehingga dalam kehidupan nyata dilihat akan pengaruh arus globalisasi dari usia sampai kepribadian manusia memiliki aspek serta kreteria yang hamper mirip (membentuk ras serumpun). Sifat nasionalisme memberikan simbol kepada masyarakat sehingga yang berbentuk penguasaan setiap daerah atau tempat ada batasan-batasan yang mengaturnya.

Zaman Sukarno dulunya nasionalisme merupakan ideologi negara sehingga sistem akan pemerintahan secara konstitusional. Gagasan nasionalisme itu juga dirasakan sebagai wujud untuk mencari bentuk pemerintahan yang baik dan pas bila dipakai atau diterapakan pada masyarakat Indonesia. Tapi pada zaman orde baru nasionalisme hanya dipakai simbol-simbol politik saja yang arahnya tergantung pada pemerintah (satu komando) dari atas dan masyarakat harus mengikutinya secara menyeluruh, kalau tidak maka terjadi ada hukuman serta perlakuan yang kurang baik dari pemerintah (kurang dapat menerima) pendapat orang lain.
Kesemuannya itu merupakan simbol saja sehingga ada yang menyatakan akan hukum itu merupakan aturan belaku pada orang kecil bukan pada orang besar, dan dalam prakteknya banyak penyimpangan-penyimpangan disanasini oleh aparatur negara demi memenuhi salah satu kepenting kelompok penguasa. Hal semacam ini membuat masyarakat tidak sepaham, dengan demikian terjadinya masalahmasalah dari kecemburuan social sampai pertentangan dalam bentuk kekerasan dari masyarakat yang merasakan diperlakukan tidak adil dan tidak boleh melakukan hal lain selain yang diatur oleh aparat pemerintah, walaupun aparat pemerintah salah dalam mengaplikasikannya tetap dibenarkan secara hukum namun sebaliknya nasib masyarakat terkadang yang benarpun disalahkan.

Dilihat dari timbulnya ilmu pengetahuan itu didasari oleh: (1). Pada hakikatnya ilmu pengetahuan timbul karena adanya hasrat ingin tahu manusia terhadap aspek-aspek kehidupan; (2). Setelah manusia memperoleh pengetahuan tentang sesuatu, kemudian diteruskan dengan penemuan secara kebetulan, melakukan percobaan, dan penelitian ilmiah; (3). Penelitian ilmiah dilakukan 
manusia untuk menyalurkan hasrat ingin tahu yang telah mencapai tarap keilmuan, disertai keyakinan bahwa setiap gejala dapat ditelaah dan dicari sebab-akibatnya; dan (4). Suatu penelitian dimulai apabila seseorang berusaha memecahkan masalah secara sistematis dengan metodemetode tertentu, yaitu metode-metode ilmiah untuk menemukan kebenaran.Jadi penelitian merupakan bagian pokok dari ilmu pengetahuan bertujuan lebih mengetahui dan mendalami segala segi kehidupan untuk memperkuat ilmu pengetahuan.

Selanjutnya fungsi sosiologi mengarahkan kepada beberapa hal diantaranya: (1). menyediakan pandangan mengenai lingkungan sosial secara lebih baik, sekaligus bisa meneliti kembali kehidupan masyarakat; (2). membantu manusia memahami diri dan lingkungannya tentang peranan kekuatan sosial dalam masyarakat; (3). memberikan berbagai wawasan baru mengenai keluarga, interaksi sosial, hubungan sosial dan perubahan sosial; (4). memberikan informasi dan pandangan baru mengenai masalah sosialbudaya yang dihadapi anggota masyarakat; (5). memberikan kemampuan dasar untuk mengetahui mengapa masyarakat bertindak dengan cara yang mereka lakukan; dan (6). memudahkan manusia mengenal seluk-beluk tradisi adat, memperluas pengetahuan mengenai perbedaan perilaku sosial, dan kemampuan adaptasi dengan pola tindakan baru.

Dalam Wijaya Kusuma (2010 : 39-40) menyatakan bahwa etika amat berperan pada semua diskusi mengenai ilmu. Kemungkinan menerapkan ilmu menjadi makin mengesankan, seiring juga makin mengeriakan. Ingat saja akan teknik, perawatan medis, melakukan pengaruh psikis, ilmu organisasi dan komunikasi. Semua penerapan ini tidak termasuk ilmu, baik ilmu murni maupun ilmu terapan, namun sangat berpengaruh pada manusia modern, juga pada ilmuwan.Dalam kebijakan dunia pendidikan, dunia usaha, dan negara, ilmu dimanfaatkan secara sadar.Karena putusan politis munculllah arus uang yang mendorong bagian ilmu tertentu.Kadang-kadang ini pertamatama berkaitan dengan ilmu terapan, tetapi langsung ada dampak juga pada ilmu murni. Munculnya computer merangsang antara lain perkembangan logika metematis, perjalanan manusia, pengaruh keadaan pada perilaku, dan politik, 
memuncak pada masalah etis, kendati etika sebagai etika tidak termasuk kawasan ilmu sendiri yang relatif otonom.

Berangkat dari hal tersebut dengan manusia memiliki etika atau moral maka dengan sendirinya mereka memiliki akhlak yang baik. Dan yang terpenting dapat membedakan mana yang baik dan mana yang buruk yang selalu berdasarkan pada akal sehat karena perkembangan akan ilmu harus dibarengi dengan pemahaman moral serta etika secara baik, biar hasilnya dapat diterima oleh semua pihak.

Dalam Wijaya Kusuma (2010 : 79-80) menyatakan bahwa etika sosial berfungsi membuat manusia menjadi sadar akan tanggungjawabnya sebagai manusia dalam kehidupannya sebagai anggota masyarakat, menurut semua dimensinya. Demikian juga etika profesi yang merupakan etika khusus dalam etika social mempunyai tugas dan tanggungjawab profesi dan tanggungjawab sebagai ilmuan yang melatar belakang corak pemikiran ilmiah dan sikap ilmiahnya.

Etika dalam kehidupan bermasyarakat sudah menjadi barang mutlak untuk mencapai sebuah kebaikan (bisa melihat benang merah dan hitam dalam mencerna serta menjalankan roda kehidupan).Setiap aspek kehidupan harus dengan serius diperhatikan etika dalam pengamalan segi kehidupan bersama demi terciptanya kerukunan, kedamaian serta kesetaraan dalam stratafikasi sosial. Etika sendiri memiliki makna yang kuat dalam memberikan input dalam setiap melakukan kegiatan bukan cuma dalam interkasi dimasyarakat lebih luas interaksi yang terbangun pada kantor (pegawai) dalam melakukan aktivitas kantor ada etika yang mengaturnya, hal inilah dikatakan etika profesi.

Dalam Jujun S. Suriassumantri (2003 : 239) menyatakan bahwa untuk membahas ruang lingkup yang menjadi tanggung jawab seorang ilmuwan maka hal ini dapat dikembalikan kepada hakikat ilmu itu sendiri. Sikap sosiial seorang ilmuan adalah konsesten dengan proses penelaahan keilmuan yang dilakukan. Sering dikatakan orang bahwa ilmu itu terbatas dari system nilai.IImu itu sendiri netral dan para ilmuwanlah yang memberinya nilai. Dalam hal ini maka masalah apakah ilmu itu terikat atau bebas dari nilai-nilai tertentu, semua itu tergantung kepada langkahlangkah keilmuan yang bersangkutan dan bukan kepada proses keilmuwan secara keseluruhan. Katakanlah 
umpamanya seorang ilmuwan dibidang hukum bersuara mengenai praktek ketidakadilan dibidang hukum dan bersikap lantang agar masalah ini dijadikan obyek penyelidikan. Bisakah kita katakana bahwa dia tidak didorong oleh nilai-nilai tertentu yang menyebabkan dia terikat oleh masalah tersebut?.

Seseorang ilmuwan harus dapat menempatkan dirinya pada posisi serta letak yang sebenarnya, sehingga tidak terjadi kesalah pahaman akan makna ilmu yang ada. Upaya-upaya ini harus selalu dibangun untuk melahirkan tanggung jawab para ilmuan terhadap apa yang menjadi buah pikirannya. Sebuah delema kalau para ilmuan leaps tangan akan ilmu yang dipikirkannya, karena ilmu yang atau sebuah teori dikemas harus melihat aspek manfaat juga mempertimbangan aspek mudaratnya, sehingga ilmuan tersebut benar-benar dikatakan sebagai ilmuan yang memiliki kredibilats tinggi karena memiliki moral (etika dan akhlak).

Dalam menghadapi berbagai masalah serta kekeliruan para ilmuan harus berbuat serta berpikir bijak, apalagi para ilmu sosiologi harus mampu menyelesaikan masalahmasalah (gejala-gejala) menyimpang dalam interaksi serta komunikasi yang dibangun dalam masyarakat. Para ilmua sosiologi juga dapat memberikan tawaran akan solusi terbaik dalam penyelesaian masalah, apalagi masalah tersebut berkaitan dengan harkat hidup orang banyak harus cepat diatasi karena kalau terlambat atau salah memberikan solusi maka akan berakibat patal dalam masyarakat. Terkadang orang yang tidak memiliki keilmuan yang memadai sangat mudah percaya akan isu-isu walaupun kebenaran masih sangat diragukan. Disinilah letak tanggung jawab moral ilmuan sosiologi dalam menyelesaikan secara bijak dan tidak memihak.Netralitas harus dijunjung tinggi dalam memberikan tawaran solusi dalam artian tidak ada keperpihakan dari ilmuan dalam menyelesaikan masalah walaupun yang dihadapinya adalah bagian dari dirinya.

Di ungkapkan kembali dalam Jujun S. Suriassumantri (2003 : 244) mengenai proses menemukan kebenaran ilmiah mempunyai implikasi etis bagi seorang ilmuwan. Karekteristik proses tersebut merupakan kategori moral yang melandasi sikap etis seorang ilmuwan. Kegiatan intelektual yang meninggikan kebenaran sebagai tujuan akhirnya mau tidak mau sebagai jalan 
pikirannya namun seluruh jalan hidupnya.Dalam usaha masyarakat untuk menegakkan kebenaran inilah maka seorang ilmuwan terpanggil oleh kewajiban sosialnya, bukan saja sebagai penganalisa materi kebenaran tersebut namun juga sebagai prototype moral yang baik.

Namun dalam etika ilmuwan seorang ilmuwan tidak lagi memberikan informasi (kabar) tetapi lebih dari itu harus dapat memberikan contoh bagaimana sebenarnya kegunaan serta cara piker sebuah pengetahuan yang berkembang. Hal ini juga dituntut haris mampu tampilan gemilang didepan orang serta memiliki sikap obyektif, terbuka serta mau mendengarkan masukkan dari orang lain dalam upaya penyempurnaan, walaupun pada dasar manusia tidak ada yang sempurna tetapi setidaknya harus dapat memperkecil kesalahan serta dosa. Orang baik adalah bukan orang tidak pernah salah tetapi dia belajar serta memperbaiki kesalahan yang diperbuatnya dengan mengunakan akal sehat.

Sebagai contoh sederhana dalam mendidik buah hati (anak) /keturunan kita menjadi pintar sering kali mengabaikan akan asas moral serta etika, sebaiknya disamping memberikan pelajaran kepada seorang anak menuju kearah kecerdasan akalnya harus selalu diimbangi dengan moral serta etika. Ini lah yang menjadi tanggung jawab moral para ilmuan akan ilmu yang dimilikinya.

Hal penting yang harus dipahami kita bersama adalah berbuat serta memberi sesuatu yang baik maka akan terasa nikmat untuk dilihat dan dinikmati. Ketika memberikan yang terbaik maka muncul rasa kepuasan akan makna dari sebuah ilmu dimiliki seseorang karena memberi dampak yang dapat dinikmati bukan cuma orang yang memiliki ilmu tetapi juga dirasakan oleh orang lain. Keberadaan para ilmuan harus benarbenar dirasakan oleh semua masyarakat itu yang menjadi tanggung jawab para ilmuwan, keberadaan ilmuwan memberikan dampak positif bagi masyarakat bukan sebaliknya.

\section{Kesimpulan}

Dari uraian di atas dapat ditarik sebuah kesimpulan sederhana akan tanggung jawab dari para ilmuan sosiologi dalam mengamalkan keilmuan yang dimiliki merupakan hal yang harus dilakukan. Dengan keberadaannya ditengah-tengah 
masyarakat dapat membawa aroma postif pada masyarakat, mengarahkan manusia menjadi lebih baik merupakan hal yang harus dilakukannya.Hal ini dilakukan sebagai perwujudan keberadaannya dalam masyarakat.Memberikan contoh serta solusi dalam kehidupan keseharihariannya menjadi kode etik keilmuan yang dimilikinya, dengan ada dirinya dapat memberikan kecerahan dalam dunia kemasyarakatan, hal tersebut benar-benar dirasakan bukan cuma hipotesis serta asumsi tetapi aplikasi dalam kehidupan itu yang dituntut dari bukti nyata keberadaannya.

Problem etika serta moral sangat menentukan arah serta tingkah laku para ilmuan sosiologi dalam mengembangan buah pikirnya dalam kenyataan kehidupan terbangun dalam suatu komunitas kehidupan. Hal tersebut perlu dilakukan dalam upaya menciptakan keserasian serta kerukunan berkehidupan bermasyarakat. Interkasi serta komunikasi yang terbangun dalam masyarakat selalu tercerminkan akan moral serta etika para ilmuwan yang professional dalam penerapan keilmuan yang dimilikinya. Pada akhinya semoga para ilmuwan terutama ilmuwan sosiologi memiliki tanggung jawab moral dan selalu memberikan contoh yang terbaik dalam masyarakat.

\section{Daftar Pustaka}

Abdullah Nashih Ulwan. 1995. "Pendidikan Anak Dalam Islam 2".Jakarta: Pustaka Amani.

H.A. Mustofa. 2009. "Filsafat Islami". Bandung: Pustaka Setia

H. Sirajuddin Zar. 2004. "Filsafat Islami". Jakarta: PT Raja Grafindo Persada.

Jujun S. Suriassumantri. 2003 "Filsafat IImu: Sebuah Pengantar Populer". Jakarta: Pustaka Sinar Harapan, Anggota IKAPI .

Louis O. Kattsoff alih bahasa Soejono Soemargono. 2003. "Pengantar Filsafat". Yogyakarta: Tiara Wacana Yogya.

Mahjudin. 2001. "Kuliah Akhlak Tasawuf".Jakarta: Kalam Mulia.

Wijaya Kusuma. 2010. "Bahan Ajar 2010-2011 Filsafat IImu Pengetahuan". Pontianak: Fakultas IImu Sosial \& IImu Politik Universitas Tanjungpura Program Magester IImu Sosial. 